\title{
Allometry, sexual selection, and evolutionary lines of least resistance shaped the evolution of exaggerated sexual traits within the genus Tyrannus
}

Fasanelli, $\mathrm{MN}^{1,2 *}$; Milla Carmona $\mathrm{P}^{2,3 *}$, Soto, $\mathrm{IM}^{1,2} \&$ Tuero $\mathrm{DT}^{1}$

1 Instituto de Ecología, Genética y Evolución de Buenos Aires - IEGEBA (CONICET-UBA), Departamento de Ecología, Genética y Evolución -DEGE, Facultad de Ciencias Exactas y Naturales, Universidad de Buenos Aires, Int. Guiraldes 2160, Buenos Aires, Argentina.

2 Laboratorio de Biología Integral de Sistemas Evolutivos. DEGE, Facultad de Ciencias Exactas y Naturales, Universidad de Buenos Aires, Int. Guiraldes 2160, Buenos Aires, Argentina.

3 Laboratorio de Ecosistemas Marinos Fósiles, Instituto de Estudios Andinos Don Pablo Groeber (CONICETUBA), Intendente Güiraldes 2160, Ciudad Universitaria, C1428EHA Buenos Aires, Argentina.

*Both authors equally contributed to the present study.

Corresponding author: Ignacio M. Soto email: soto@ege.fcen.uba.ar 
bioRxiv preprint doi: https://doi org/101101/2021.07 09.451836; this version posted July 11 2021. The copyright holder for this preprin (which was not certified by peer review) is the author/funder, who has granted bioRxiv a license to display the preprint in perpetuity. It is made available under aCC-BY-NC-ND 4.0 International license.

\begin{abstract}
Variational properties hold a fundamental role in shaping biological evolution, exerting control over the magnitude and direction of evolutionary change elicited by microevolutionary processes that sort variation, such as selection or drift. We studied the Tyrannus genus, as a model for examining the conditions and drivers that facilitate the repeated evolution of exaggerated, secondary sexual traits in the face of significant functional limitations. We study the role of allometry, sexual selection, and their interaction on the diversification of tail morphology in the genus, assessing whether and how they promoted or constrained phenotypic evolution. The exaggerated and functionallyconstrained long feathers of deep-forked species, T. savana and T. forficatus, independently diverged from the rest of the genus following the same direction of main interspecific variation common to the entire cluster of species. However, at a macroevolutionary scale those axes summarising both sexual dimorphism and allometric variation of the deep-forked species were aligned with the between-species maximum variation axis of non deep-forked species. Thus, we are presenting evidence of amplified divergence via the co-option and reorientation of allometric shape variation involved in a sexual selection process that repeatedly drove morphology along a historically favoured direction of cladogenetic evolution.
\end{abstract}

Key words: constraints, morphology, birds, tails, diversification

\title{
Introduction
}

The direction and magnitude of evolutionary change are largely controlled by evolutionary processes that sort variation such as natural selection and drift [1,2], but also by the sources of that variation, such as the genetic architecture underlying the affected phenotypes [3]. Intrapopulational variation per se is a major evolutionary factor that can enhance or impede response to selection by 
bioRxiv preprint doi: https://doi org/10.1101/2021.07.09 451836; this version posted July 11,2021 . The copyright holder for this preprint (which was not certified by peer review) is the author/funder, who has granted bioRxiv a license to display the preprint in perpetuity. It is made available under aCC-BY-NC-ND 4.0 International license.

modulating the amount of raw material available for phenotypic changes elicited by other processes [4,5]. Over short evolutionary timescales, selective responses may be biased by strong genetic correlations or simply by the absence of genetic variation thus precluding or deviating evolutionary change towards certain phenotypes [6-8]. This includes the early stages of betweenspecies divergence, where evolution is predicted to be biased along "genetic lines of least resistance" defined by the additive genetic variance-covariance matrix " $G$ " $[4,9]$.

However, natural selection has its agency at the organismal level, acting upon available phenotypic variation [1]. As the organismal phenotype is the result of developmental processes unfolding during ontogeny, the latter can favour the emergence of particular phenotypes (e.g. [10]), and thus has the potential to establish preferred directions for long-term evolution [11]. In this sense, they constitute "phenotypic lines of least resistance" defined by $P$, the phenotypic variancecovariance matrix (see [12]). The influence of these constraints is well documented for relatively short evolutionary timescales (i.e., less than 2 million years; [4,13-18];see [19] for a discussion).

Nonetheless, the influence of genetic and developmental constraints over greater evolutionary timescales is yet to be determined $[1,20]$ as empirical studies are scarce (but see $[19,21])$. Genetic constraints are frequently disregarded when studying species diversification or other long-term evolutionary phenomena under the argument that the genetic architecture of trait covariation may evolve as well [22-24] consequently altering potential genetic lines of least resistance [25]. Selection and drift can alter the G matrix [23,26-28] but the signature of genetic constraint may persist over large timescales even in the presence of an evolving genetic architecture [19].The study of phenotypic lines of least resistance can greatly improve the study of developmental constraints, as it is both easier to estimate than and highly correlated to their genetic counterpart, as well as highly informative in regard to evolution (e.g., [12,29]).

Allometry is a classic example of trait covariation and a central issue in the literature addressing developmental integration, as changes in many morphological, physiological and life history traits are highly correlated with changes in organ or body size [30-32]. Because ontogenetic and evolutionary allometric relationships are often evident over large size ranges, and since allometric slopes (both static and ontogenetic) are usually rather conserved among closely 
bioRxiv preprint doi: https://doi org/10.1101/2021.07 09.451836; this version posted July 11 2021. The copyright holder for this preprint (which was not certified by peer review) is the author/funder, who has granted bioRxiv a license to display the preprint in perpetuity. It is made available under aCC-BY-NC-ND 4.0 International license.

related species, allometry has been considered as a constraint for morphological evolution $[10,33,34]$. In this view, the existence of allometric patterns is often interpreted as evidence of strong ontogenetic, physiological or other biological mechanisms that restrain or limit the rate and direction of evolution and diversification $[35,36]$. An alternative view is to consider the processes underlying the observed allometric patterns as facilitators of evolution or an adaptation on itself [30,37-40]. Under this perspective, which is often discussed in the context of classic studies ([30]; see a discussion in [41]), the effect of selective processes that shape trait relationships or phenotypic responses are amplified by the existent covariance structure.

This latter view is widespread in ornithological studies, as allometric patterns are considered a major factor contributing to phenotypic variation across a range of avian clades $[42,43]$. Previous studies focused on avian traits (beaks, tails and wings) showed how ecological factors drive the evolution of those structures with the aid of allometry [44-46]. For example, Bright et al. [47] found a strong covariation between skull shape and size, showing that exploitation of allometric relationships is an effective mechanism by which raptor birds may modify their feeding ecology.

Tyrannus (Lacépède 1799) is a New World genus of passerines comprising thirteen species with a common ancestor about 5 MY before present and with a widespread American distribution, from Canada to Argentina $[44,48,49]$. Those species inhabit a wide range of environments, such as savannahs, woods and even urban areas [50,51] Some species are seasonal migrants, although migratory behaviours within the genus are variable (e.g., partial, short-distance and long distance migration; $[49,52,53])$. They prey primarily on flying insects and forage almost exclusively during flight, although they also feed from high perches or on the ground [54-56]. The group includes two deepfork-tailed (hereafter, DF) species, the Scissor-tailed ( $T$. forficatus) and the Fork-tailed ( $T$. savana) Flycatchers, from North America and South America, respectively (Figure 1, [51,57,58]).

Derived from independent monophyletic lineages [59], these DF species present disjunct geographic distributions [60] and are characterised as socially monogamous, with both male and female involved in parental care [61]. Both species show extremely elongated tails in males and females, as well as a significant sexual dimorphism in tail length attributed to the action of sexual selection $[58,62,63]$. 
Here, we address the genus Tyrannus as a model for examining the conditions and drivers that facilitate the repeated evolution of exaggerated, secondary sexual traits in the face of significant functional limitations, with particular focus on the role of allometry, sexual selection, and their covariation, on the diversification of tail morphology in the genus. In particular, we estimate and explore the relationship between two major sources of intraspecific variation (sexual dimorphism and allometric variation) and the main directions of macroevolutionary change that accrued during the evolution of the clade, assessing whether they promoted or otherwise constrained the evolution of tail morphology by establishing phenotypic lines of least resistance.

\section{Materials and methods}

\section{Data collection}

The thirteen species of Tyrannus were represented in a sample of 281 museum specimens (range: 12-39 specimens per species, average: 21.6 specimens per species; American Museum of Natural History, AMNH, USA and Museo Argentino de Ciencias Naturales, MACN, Argentina). Only adult skins of both sexes with rectrices in good condition were included.

Tails were photographed in dorsal view from a standardised vertical plane. Tail morphology was captured by placing nine landmarks on the image of the open tail of each specimen: 1) the tips of the central rectrix, as well as \#2-\#5) the two outermost rectrices, \#6-\#7) the pygostyle insertion point, and \#8-\#9) the inflection point formed by the opened outer rectrix at the base of the tail of each side (Figure 1).

Due to the fragile feathers of museum material, tails were only opened at an angle of $60^{\circ}$ (Figure 1A). Since an opening of $120^{\circ}$ is the standard in studies of bird tail morphology [66], the two landmarks marking the tip of the outermost rectrices of each side were further rotated $30^{\circ}$, using the centroid of landmarks \#6-\#9 (defining the 'base' of the tail) as pivot. In order to avoid problems reported elsewhere for supervised versions of Principal Component Analysis (PCA) and 
bioRxiv preprint doi: https://doi.org/10.1101/2021.07 09.451836; this version posted July 11 2021. The copyright holder for this preprint (which was not certified by peer review) is the author/funder, who has granted bioRxiv a license to display the preprint in perpetuity. It is made available under aCC-BY-NC-ND 4.0 International license.

its algebraic equivalents (i.e., between-group PCA and Partial Least Squares; e.g.,[64,65]), the four landmarks corresponding to the left side of the tail (having served to determine the central axis of symmetry) were discarded and all subsequent analyses were carried out using the five remaining landmarks (Figure 1A; note that these landmarks were mirrored to represent tails in all figures).

Centroid size (CS) of each landmark configuration was calculated to be used as a proxy for tail size, after which the sample of landmark configurations was subjected to Generalized Procrustes Analysis and projected into tangent space [66], thus separating size from shape variation to be analysed independently.

Body size was computed for a subset of 260 specimens for which measures of wing, bill and tarsus lengths, as well as body weight, were available. A PCA of these variables was performed and the scores of specimens along the first axis were used as a body size proxy. The relationship between tail and body size was assessed by performing Linear Regressions, using raw and sexually-corrected size estimates. The latter 'correction' was performed within each species by computing theresiduals from a linear model of each size estimate on sex. Tail and body sizes were z-standardised in all cases to make values comparable.

Interspecific shape variation

Raw shape variation within each species was processed to remove intraspecific variation by computing the shape residuals resulting from a Linear Model of tail shape on tail size and sex. This 'corrected' data set was further refined by means of between-group PCA (bgPCA; see [67] and references therein), performed using all Tyrannus species but $T$. savanaand $T$. forficatus as a priori groups. These procedures were applied to avoid the heavy influence that deep-forked shapes (and to a lesser extent, the intraspecific shape variation) exert over the orientation of the axes resulting from a regular PCA. Instead, a series of synthetic shape variables (bgPCs), rotated to maximize interspecific variation among those species possessing nondeep-forked (hereafter, NDF) tail morphologies, were constructed (bgPC1 being renamed from here onward as the between-species maximum variation axis, or BMV axis). Only then, samples and mean shapes belonging to $T$. savana and $T$. forficatus were projected into the resulting bgPCs. By using the interspecific 
bioRxiv preprint doi: https://doi org/101101/2021.07.09.451836; this version posted July 11 2021. The copyright holder for this preprin (which was not certified by peer review) is the author/funder, who has granted bioRxiv a license to display the preprint in perpetuity. It is made available under aCC-BY-NC-ND 4.0 International license.

variation displayed by NDF species as the basis for constructing our shape variables, we sought to enhance interpretability of our results by establishing the main directions of evolutionary variation resulting from 'normal' within-clade dynamics as reference.

\section{Intraspecific shape variation}

Starting again from the raw shape variables, four types of intraspecific shape variation were isolated within each species. First, the axis of maximum variation (from now on, within-species maximum variation axis, or WMV axis) was estimated through the first PC resulting from a PCA of raw shape variation. Second, an axis representing allometric shape variation was constructed, using Partial Least Squares (PLS) of shape on log-transformed centroid size (in this context, this procedure finds a linear combination of shape variables maximising the correlation with changes in size; see [68]) and computing the shapes expected under the estimated relationship by sampling the range of realised PLS scores at regular intervals. Third, an axis representing differences between sexes was generated by computing male and female mean shapes along the axis resulting from a new bgPCA using sex as grouping factor. Fourth, an axis representing residual variation (i.e., not explained by changes in either size, sex or their interaction) was obtained by performing a PCA over the corresponding shape residuals. These axes were characterised using their eigenvector's coefficients and depicted by projecting their expected shapes into the morphospace.

Statistical significance of shape differences attributable to intersexual and allometric variation was assessed for each species separately through Procrustes Distances-based Linear Models (using sex and log-transformed centroid size as independent variables, respectively). The magnitude of this difference was measured using the partial Procrustes distance implied in each shape transformation. Whether the BMV and the allometric and intersexes axes are more aligned than expected by chance was tested separately for each species by comparing the Pearson correlation between the corresponding eigenvector coefficients to the distribution of the correlation between randomly permuted eigenvector coefficients, generated through 999 iterations [32]. 
bioRxiv preprint doi: https://doi.org/10.1101/2021 07.09 .451836 this version posted July 11 2021. The copyriaht holder for this preprin (which was not certified by peer review) is the author/funder, who has granted bioRxiv a license to display the preprint in perpetuity. It is made available under aCC-BY-NC-ND 4.0 International license.

\section{Macroevolutionary pattern of divergence}

A molecular phylogeny was obtained from birdtree.org and onezoom.org from Jetz et al. $[48,59]$ and Hackett et al. [69] in order to provide phylogenetic structure for the analyses (Figure 1B). Both tail shapes and patterns of intraspecific variation were reconstructed for hypothetical ancestors by optimising the species' mean shape configurations and sets of corresponding eigenvectors within a maximum parsimony framework [70]. This methodology reconstructs ancestral traits maximising similitude accounted for common ancestry. Phylogenetic structure was included in morphospaces by projection of shape configurations corresponding to the tips and nodes of the phylogeny, along with their genealogical relationships, to create a phylomorphospace [71].

Finally, in order to explore whether between-species divergence took place along lines of least resistance, as well as the nature of those lines, the alignment between axes was tested for every possible triad of an ancestor and its two descendants, using the same permutation test approach described above. These comparisons correspond to a) the alignment between the interdescendants axis (i.e., the bgPC separating the pair of descendants' shapes) and the ancestral WMV, and b) the alignment between the ancestral WMV and ancestral allometric, intersexes, and residual axes of variation.

All analyses were conducted in the R environment [72] using the packages Morpho [73], geomorph [74], shapes [75], abind [76], retistruct [77], spdep [78], ape [79] and phytools [80]. The only exceptions were the digitisation of tail landmarks, carried out using tpsDig [81] and the ancestral node reconstruction, implemented in Tree Analysis using New Technology (TNT; [82]).

\section{Results}

Size and shape

Raw body and tail sizes displayed a significant positive correlation in four out of the 13 species of Tyrannus: T. forficatus, T. niveigularis, T. savana and T. tyrannus. However, this correlation was lost 
bioRxiv preprint doi: https://doi org/101101/2021.07.09.451836; this version posted July 11 2021. The copyright holder for this preprin (which was not certified by peer review) is the author/funder, who has granted bioRxiv a license to display the preprint in perpetuity. It is made available under aCC-BY-NC-ND 4.0 International license.

in the two deep-fork-tailed species when the sexually-corrected sizes were used instead (Figure 2, Supplementary Table 1).

The first three Principal Components resulting from bgPCA accounted for $98.91 \%$ of the corresponding variance (Figure 3A-D, Supplementary Figure 1). Variation along the first $\operatorname{bgPC}(\mathrm{BMV}$, capturing $72.86 \%$ of the original shape variance) describes differences in the degree of forking of the tail and relative base width, with negative values representing forked tails with outermost rectrices slightly more elongated that inner outer rectrices, and positive values representing rounded tail fans. The second bgPC (20.95\% of total variance explained) on the other hand captures differences in tail elongation, tail base width and relative positions of the tips of outermost rectrices relative to the sagittal plane. Finally, bgPC3 $(5.11 \%$ of the original shape variance) represents subtle differences in separation of outermost rectrices' tips. Most Tyrannus species display an overlapped distribution in the resulting phylomorphospace. Unsurprisingly, $T$. savana and T. forficatus are the exception, diverging markedly from the rest of the genus along bgPC1, and from each other along bgPC3 (Figure 3A-B).

Inter- and intraspecific shape variation

In general, Tyrannus species with NDF tails displayed a reduced allometric and intersexes variation (with the exception of sexual dimorphism in $T$. albogularis), as evidenced by both the magnitude and statistical significance of the implied shape transformations (Table 1). These axes are significantly aligned with each other in four species (Table 2). However, although their alignment with the BMV axis differ (Figure 3C-D), none of these species display a significant correlation between the latter and allometric or intersexes axes (the sole exception being the intersexes axis of T. dominicensis; Table 2, Figure 3C-D).

The situation changes dramatically for the DF species, as both $T$. savana and $T$. forficatus exhibit significant allometric and intersexes variation (Table 1). However, the most remarkable aspect of these species is the alignment of both allometric and intersexes axes of variation not only 
with each other, but with the main BMV axis of the NDF Tyrannus species (i.e., they are approximately parallel; Table 2, Figure 3C-D).

As for the ancestor-descendants comparisons, most of the correlation between the different reconstructed types of intraspecific variation and the reconstructed ancestral WMVaxis can be attributed to residual variation (Table 3). In this regard, the main difference between comparisons excluding and focused on DF species is an increased contribution (roughly 50\%) of allometric variation for the latter in relation to the former. The pattern of contribution of the different reconstructed types of intraspecific variation to the correlation with the reconstructed interdescendants axis was very similar for comparisons involving only NDF tailed species. In contrast, intersexes variation accounted for most of the correlation between the reconstructed ancestral WMV and the reconstructed inter-descendants axis of variation in comparisons involving only DF species (Table 3).

\section{Discussion}

Allometric patterns are important aspects contributing to diversification of avian morphology $[42,43]$, in concert with ecological pressures on phenotypes [44-47]. Sexual selection is also an important evolutionary force in the context of avian evolution, affecting behaviour, colouration and morphology of birds $[83,84]$.

In the context of bird tail morphology and sexual selection, this topic has received considerable attention $[38,40,42]$ being generally addressed from the 'classic' Huxley-Jolicoeur school of allometry, i.e., by studying the relation between tail and body size [85]. The general consensus emerging from these studies is that secondary sexual traits with exaggerated morphologies will tend to show positive allometry (i.e., larger tails will be associated with larger bodies) as the result of the balance between metabolic costs and reproductive advantage. Our findings support this prediction, as both $T$. savana and $T$. forficatus show positive tail-to-body size allometry (Figure 2, Suplementary Table 1). 
bioRxiv preprint doi: https://doi org/10.1101/2021.07 09.451836; this version posted July 11 2021. The copyright holder for this preprint (which was not certified by peer review) is the author/funder, who has granted bioRxiv a license to display the preprint in perpetuity. It is made available under aCC-BY-NC-ND 4.0 International license.

However, these results represent only the first of two very different allometric phenomena this study is concerned with. The second, and the one that is the main focus of this work, is the relation between trait size and shape (framed within the 'modern' Mosimann-Gould approach to allometry; [85]). A very straightforward takeaway from our results is that this kind of allometric variation and sexual dimorphism are both amplified and evolutionary coupled in the two independently evolved Tyrannus species with exaggerated tail morphologies (Figures 2-3). Ongoing sexual selection has been reported in both $T$. savana and $T$. forficatus $[58,62]$. Still, the coupling of sexual dimorphism (a natural by-product of sexual selection $[86,87]$ with allometric shape variation suggests that this powerful agent of evolutionary change is being fed with a pervasive and ecologically significant source of morphological variation. This is in line with the notion that sexual selection has played a central role in the evolution of exaggerated tail morphologies in birds [88-91], but also shines light on why such disparate shapes have been able to be realised in the first place.

Nonetheless, there are several other Tyrannus species showing both coupled patterns of intersexual and allometric shape variation and NDF tails (Table 2). The missing piece lies in another result: the marked morphological differences between $T$. savana and T. forficatus and the rest of the genus can be summarised as a monotonic divergence along the same direction of main interspecific variation extracted from the cluster of species with NDF tails (the BMV). But perhaps the most striking finding of this study is that, at a macroevolutionary scale, axes summarising both sexual dimorphism and allometric variation of $T$. savana and T. forficatus are aligned with the BMV of NDF species.

This latter axis can be considered as resulting from the accumulation of cladogenetic change (under the reasonable assumption of the prevalence of non-directional anagenetic patterns of change; [92]), and will therefore reflect the directions of phenotypic evolution favoured during between-species divergence associated to regular within-clade dynamics in Tyrannus. This divergence follows the direction of maximum intraspecific variation present in the ancestor -mainly corresponding to residual intraspecific variation, with modest contributions of sexual dimorphism and allometry- for the majority of the cladogenetic events involving the evolution of NDF species 
bioRxiv preprint doi: https://doi org/10.1101/2021.07 09.451836; this version posted July 11 2021. The copyright holder for this preprint (which was not certified by peer review) is the author/funder, who has granted bioRxiv a license to display the preprint in perpetuity. It is made available under aCC-BY-NC-ND 4.0 International license.

(Table 3). Thus, regular within-clade phenotypic evolution can be regarded as following a prevailing phenotypic line of least resistance [4]. In speciation events leading to a DF species, however, the overall contribution of allometry to ancestral intraspecific variation is substantially higher. Moreover, interdescendants divergence correlates strongly with ancestral sexual dimorphism, hinting the action of sexual selection (Table 3). Putting all this information together, we suggest that two conditions are necessary for the evolution of exaggerated tails in Tyrannus: 1) the co-option of allometric shape variation as the primary source of raw material for sexual selection, and 2) the alignment of the latter process with a macroevolutionary line of least resistance, resulting in fast divergence through an open lane of macroevolutionary change.

If these lessons can be generalised, we should expect other cases of sexually-related exaggerated or highly elaborated traits to represent an amplification of 'regular' within-clade dynamics, catalysed by a process of sexual selection and fuelled by allometric -or perhaps other substantial intraspecific source of- morphological variation. In particular, we predict that 1) species with exaggerated or elaborated morphologies will diverge along the main axis of interspecific variation already present in the cluster of related species with regular morphology, and 2) the latter axis will be aligned with the axes describing intraspecific differences between sexes and allometric (or other kinds of) morphological variation.

Ornithological literature has openly understood the design of bird tail as a flight device, not only from the historically-vast observational registers, but most probably through the widely used theoretical models of bird flight. A 'functionalist' approach has been heavily supported when addressing the evolution of the many bird species showing marked sexual dimorphism and elaborated tail morphologies (e.g., [86,87,91]), with most of the literature revolving around the relative contribution and putative antagonism of natural and sexual selection. In this context, net selection on tail's morphology is conceived as the compromise between its role as secondary sexual trait -i.e., its effects on mating success- and as a structure involved in flight -i.e., its effects on aerodynamic performance- [89,93], invoking both biomechanical conflicts [94](Evans 2004) and physiological trade-offs [95,96]. 
In contrast, the other side of the functionalist coin, namely the 'structuralist' aspects (i.e., general biases in the production of variation that introduce limits, but also channels, for evolution; see [1]) of this study case, have received much less attention. The existence of variation, long recognised as the water to selection's mill, has been generally treated as something that is given (or not) for tail form without further consideration. Even allometry, a topic subject to recent debate, is treated as an expression of the tension between natural and sexual selection (see above). Yet, the present study hints that the existence of some highly elaborated morphologies (a feature strongly associated with selection) crucially depends on the interaction of different types, levels and specific properties of variation. Our intention is not to argue against the importance of selection (a process our results are consistent with), but to vindicate the creative role that evolutionary changes in direction, magnitude and coupling of different sources of variation (whatever their particular mechanistic base might be) plays into reaching a satisfactory explanation. In this particular case, the co-option (and potential reorientation) of allometric shape variation as a source of raw material for processes of sexual selection driving mean morphology along a historically favoured direction of cladogenetic evolution resulted in amplified divergence.Evolutionary changes in the properties of variation, as well as their feedback with selection and other processes, need not to follow the same evolutionary dynamics than the current selective regimes identified and discussed so far in the literature, and represent an open avenue for future research.

\section{Acknowledgments}

We are grateful to the curators, technicians and collection managers of the bird divisions of The American Museum of Natural History (George F. Barrowclough, Joel L. Cracraft and Paul Sweet) and the Museo Argentino de Ciencias Naturales "Bernardino Rivadavia" (Darío Lijtmaer and Yolanda Davies) for access to materials under their care and for their kind assistance. MNF was a recipient of a Collection Study Grant from The Frank M. Chapman Memorial Fund of the AMNH Museum.

\section{Funding}


This work was supported by the National Research Council of Argentina (PIP 2017-2019, CONICET), National Agency for Scientific and Technological Promotion (PICT-2017-0134, PICT2017-0220) and University of Buenos Aires (UBACyT 2018-2019) funds granted to DTT and IMS. Funding agents had no role in study design, data collection and analysis, decision to publish, or preparation of the manuscript.

\section{Authors contributions}

MNF collected the primary data, performed the morphometric quantification, participated in data analysis and in the design of the study and critically revised the original draft.

PMC conceived and participated in the conceptualization and design of the study, carried out the data analysis and visualisation and drafted the manuscript along with IMS.

IMS conceived the study and contributed to the study conceptualization and design, coordinated the study, provided funding, contributed to the data analysis and statistics and drafted the manuscript along with PMC.

DTT conceived and coordinated the study, participated in the design of the study, provided funding and critically revised the original draft.

All authors performed revisions and editing of the initial draft and gave final approval for publication and agreed to be held accountable for the work performed therein.

\section{Competing interests}

Authors declare no competing interests.

\section{References}

1. Gould SJ. 2002 The structure of evolutionary theory. Harvard University Press. (doi:10.2307/j.ctvjsf433)

2. Jablonski D. 2017 Approaches to macroevolution: 1. general concepts and origin of variation. Evol. Biol. 44, 427-450. (doi:10.1007/s11692-017-9420-0) 
3. Lande R. 1979 Quantitative genetic analysis of multivariate evolution, applied to brain: body size allometry. Evolution 33, 402-416. (doi:10.2307/2407630)

4. Schluter D. 1996 Adaptive radiation along genetic lines of least resistance. Evolution 50, 1766-1774. (doi:10.1111/j.1558-5646.1996.tb03563.x)

5. Etterson JR, Shaw RG. 2001 Constraint to adaptive evolution in response to global warming. Science 294, 151-154. (doi:10.1126/science.1063656)

6. Arnold SJ. 1992 Constraints on phenotypic evolution. Am. Nat. 140, S85-S107. (doi:10.1086/285398)

7. Blows MW, Hoffmann AA. 2005 A reassessment of genetic limits to evolutionary change. Ecology 86, 1371-1384. (doi:10.1890/04-1209)

8. Walsh B, Blows MW. 2009 Abundant genetic variation + strong selection = multivariate genetic constraints: a geometric view of adaptation. Annu. Rev. Ecol. Evol. Syst. 40, 41-59. (doi:10.1146/annurev.ecolsys.110308.120232)

9. McGuigan K. 2006 Studying phenotypic evolution using multivariate quantitative genetics. Mol. Ecol. 15, 883-896. (doi:10.1111/j.1365-294X.2006.02809.x)

10. Gould SJ. 1966 Allometry and size in ontogeny and phylogeny. Biol. Rev. 41, 587-638. (doi:10.1111/j.1469-185X.1966.tb01624.x)

11. Gould SJ. 1977 Ontogeny and phylogeny. Harvard University Press.

12. Marroig G, Cheverud JM. 2005 Size as a line of least evolutionary resistance: diet and adaptive morphological radiation in New World monkeys. Evolution 59, 1128-1142. (doi:10.1111/j.0014-3820.2005.tb01049.x)

13. Bégin M, Roff DA. 2004 From micro- to macroevolution through quantitative genetic variation: positive evidence from field crickets. Evolution 58, 2287-2304. (doi:10.1111/j.0014-3820.2004.tb01604.x)

14. McGuigan K, Chenoweth SF, Blows MW. 2005 Phenotypic divergence along lines of genetic variance. Am. Nat. 165, 32-43. (doi:10.1086/426600) 
15. Hansen TF, Houle D. 2008 Measuring and comparing evolvability and constraint in multivariate characters. J. Evol. Biol 21, 1201-1219. (doi:10.1111/j.14209101.2008.01573.x)

16. Chenoweth SF, Rundle HD, Blows MW. 2010 The contribution of selection and genetic constraints to phenotypic divergence. Am. Nat. 175, 186-196. (doi:10.1086/649594)

17. Bolstad GH, Hansen TF, Pélabon C, Falahati-Anbaran M, Pérez-Barrales R, Armbruster WS. 2014 Genetic constraints predict evolutionary divergence in Dalechampia blossoms. Philos. Trans. R. Soc. B 369, 20130255. (doi:10.1098/rstb.2013.0255)

18. Walter GM, Aguirre JD, Blows MW, Ortiz-Barrientos D. 2018 Evolution of genetic variance during adaptive radiation. Am. Nat. 191, E108-E128. (doi:10.1086/696123)

19. McGlothlin JW, Kobiela ME, Wright HV, Mahler DL, Kolbe JJ, Losos JB, Brodie ED. 2018 Adaptive radiation along a deeply conserved genetic line of least resistance in Anolis lizards. Evol. Lett. 2, 310-322. (doi:10.1002/evl3.72)

20. Schluter D. 2000 Ecological character displacement in adaptive radiation. Am. Nat. 156, S4-S16. (doi:10.1086/303412)

21. Houle D, Bolstad GH, van der Linde K, Hansen TF. 2017 Mutation predicts 40 million years of fly wing evolution. Nature 548, 447-450. (doi:10.1038/nature23473)

22. Turelli M, Gillespie JH, Lande R. 1988 Rate tests for selection on quantitative characters during macroevolution and microevolution. Evolution 42, 1085-1089. (doi:10.1111/j.1558-5646.1988.tb02526.x)

23. Steppan SJ, Phillips PC, Houle D. 2002 Comparative quantitative genetics: evolution of the G matrix. Trends Ecol. Evol. 17, 320-327. (doi:10.1016/S0169-5347(02)02505-3)

24. Arnold SJ, Bürger R, Hohenlohe PA, Ajie BC, Jones AG. 2008 Understanding the evolution and stability of the G-matrix. Evolution 62, 2451-2461. (doi:10.1111/j.15585646.2008.00472.x) 
25. Arnold SJ, Pfrender ME, Jones AG. 2001 The adaptive landscape as a conceptual bridge between micro- and macroevolution. In Microevolution Rate, Pattern, Process (eds AP Hendry, MT Kinnison), pp. 9-32. Dordrecht: Springer Netherlands. (doi:10.1007/978-94-010-0585-2_2)

26. Roff DA, Fairbairn DJ. 2012 The evolution of trade-offs under directional and correlational selection. Evolution 66, 2461-2474. (doi:10.1111/j.15585646.2012.01634.x)

27. Björklund M, Husby A, Gustafsson L. 2013 Rapid and unpredictable changes of the Gmatrix in a natural bird population over 25 years. J. Evol. Biol. 26, 1-13. (doi:10.1111/jeb.12044)

28. Careau V, Wolak ME, Carter PA, Garland T. 2015 Evolution of the additive genetic variance-covariance matrix under continuous directional selection on a complex behavioural phenotype. Proc. Royal Soc. B 282, 20151119. (doi:10.1098/rspb.2015.1119)

29. Renaud S, Auffray J-C. 2013 The direction of main phenotypic variance as a channel to evolution: cases in murine rodents. Hystrix It. J. Mamm. 24, 85-93. (doi:10.4404/hystrix-24.1-6296)

30. Schmidt-Nielsen K, Knut S-N. 1984 Scaling: why is animal size so important? Cambridge University Press.

31. Brown J, West G. 2000 Scaling in Biology. Oxford, New York: Oxford University Press.

32. Zelditch ML, Swiderski DL, Sheets HD. 2012 Geometric morphometrics for biologists: a primer. 2nd edn. Academic Press.

33. Björklund M. 1996 The importance of evolutionary constraints in ecological time scales. Evol. Ecol. 10, 423-431. (doi:10.1007/BF01237727)

34. Voje KL, Hansen TF, Egset CK, Bolstad GH, Pélabon C. 2014 Allometric constraints and the evolution of allometry. Evolution 68, 866-885. (doi:10.1111/evo.12312) 
35. Chernoff B, Magwene PM. 1999 Morphological integration: forty years later. In Morphological Integration (eds EC Olson, RL Miller), pp. 319-353. University of Chicago Press.

36. Murren CJ. 2012 The integrated phenotype. Integr. Comp. Biol. 52, 64-76. (doi:10.1093/icb/ics043)

37. Emlen DJ, Nijhout HF. 2000 The development and evolution of exaggerated morphologies in insects. Annu. Rev. Entomol. 45, 661-708. (doi:10.1146/annurev.ento.45.1.661)

38. Bonduriansky R. 2007 Sexual selection and allometry: a critical reappraisal of the evidence and ideas. Evolution 61, 838-849. (doi:10.1111/j.1558-5646.2007.00081.x)

39. Eberhard WG. 2009 Postcopulatory sexual selection: Darwin's omission and its consequences. PNAS 106, 10025-10032. (doi:10.1073/pnas.0901217106)

40. Bonduriansky R, Day T. 2003 The evolution of static allometry in sexually selected traits. Evolution 57, 2450-2458. (doi:10.1111/j.0014-3820.2003.tb01490.x)

41. Pélabon C, Firmat C, Bolstad GH, Voje KL, Houle D, Cassara J, Rouzic AL, Hansen TF. 2014 Evolution of morphological allometry: The evolvability of allometry. Ann. N.Y. Acad. Sci. 1320, 58-75. (doi:10.1111/nyas.12470)

42. Cuervo JJ, Møller AP. 2009 The allometric pattern of sexually size dimorphic feather ornaments and factors affecting allometry. J. Evol. Biol. 22, 1503-1515. (doi:10.1111/j.1420-9101.2009.01758.x)

43. Kulemeyer C, Asbahr K, Gunz P, Frahnert S, Bairlein F. 2009 Functional morphology and integration of corvid skulls - a 3D geometric morphometric approach. Front. Zool. 6, 2. (doi:10.1186/1742-9994-6-2)

44. Fitzpatrick JW. 1985 Form, foraging behavior, and adaptive radiation in the Tyrannidae. Ornithol. Monogr. , 447-470. (doi:10.2307/40168298) 
45. Norberg UM. 1995 How a long tail and changes in mass and wing shape affect the cost for flight in animals. Funct. Ecol. 9, 48-54. (doi:10.2307/2390089)

46. Pigot $\mathrm{AL}$, Trisos $\mathrm{CH}$, Tobias JA. 2016 Functional traits reveal the expansion and packing of ecological niche space underlying an elevational diversity gradient in passerine birds. Proc. Royal Soc. B 283, 20152013. (doi:10.1098/rspb.2015.2013)

47. Bright JA, Marugán-Lobón J, Cobb SN, Rayfield EJ. 2016 The shapes of bird beaks are highly controlled by nondietary factors. PNAS 113, 5352-5357. (doi:10.1073/pnas.1602683113)

48. Jetz W, Thomas GH, Joy JB, Hartmann K, Mooers AO. 2012 The global diversity of birds in space and time. Nature 491, 444-448. (doi:10.1038/nature11631)

49. del Hoyo J, Elliot A, Christie D, editors. 2010 Handbook of the birds of the world. Barcelona: Lynx Edicions.

50. Fitzpatrick JW et al. 2004 Family Tyrannidae (tyrant-flycatchers). In Handbook of the Birds of the World, pp. 170-462.

51. Ridgely RS, Tudor G. 2009 Field guide to the songbirds of south america: the Passerines. University of Texas Press.

52. Barry JH, Butler LK, Rohwer S, Rohwer VG. 2009 Documenting molt-migration in western kingbird (Tyrannus verticalis) using two measures of collecting effort. The Auk 126, 260-267. (doi:10.1525/auk.2009.07137)

53. MacPherson MP. 2017 Migration patterns in birds of the new world: seasonal, morphometric and physiological considerations. Tulane University, School of Science and Engineering. See https://www.proquest.com/openview/747af3ce1e93a47dcf604a10e86d5ca2/1?pqorigsite=gscholar $\& \mathrm{cbl}=18750$.

54. Fitzpatrick JW. 1980 Foraging behavior of neotropical tyrant flycatchers. Condor $\mathbf{8 2}$, 43-57. (doi:10.2307/1366784) 
55. Traylor MA, Fitzpatrick JW. 1980 A survey of the tyrant flycatchers. Living Bird

56. Murphy MT. 1983 Clutch size in the Eastern Kingbird: factors affecting nestling survival.

The Auk 100, 326-334. (doi:10.1093/auk/100.2.326)

57. Regosin JV. 1998 Scissor-tailed flycatcher (Tyrannus forficatus). The Birds of North America.

58. Tuero DT, Jahn AE, MacPherson M. 2019 Bird migration in South America: the forktailed flycatcher (Tyrannus savana) as a case study. In Behavioral Ecology of Neotropical Birds (eds JC Reboreda, VD Fiorini, DT Tuero), pp. 133-154. Cham: Springer International Publishing. (doi:10.1007/978-3-030-14280-3_7)

59. Jetz W, Thomas GH, Joy JB, Redding DW, Hartmann K, Mooers AO. 2014 Global distribution and conservation of evolutionary distinctness in birds. Curr. Biol. 24, 919930. (doi:10.1016/j.cub.2014.03.011)

60. Regosin JV. 2020 Scissor-tailed flycatcher (Tyrannus forficatus). Birds of the World.

61. Jahn AE, Tuero DT. 2020 Fork-tailed flycatcher (Tyrannus savana). Birds of the World.

62. Regosin JV, Pruett-Jones S. 2001 Sexual selection and tail-length dimorphism in Scissor-tailed flycatchers. The Auk 118, 167-175. (doi:10.1093/auk/118.1.167)

63. Roeder DV, Husak MS, Murphy MT, Patten MA. 2019 Size, ornamentation, and flight feather morphology promote within-pair paternity in a sexually dimorphic passerine. Behav. Ecol. Sociobiol. 73, 1-12. (doi:10.1007/s00265-019-2704-x)

64. Bookstein FL. 2019 Pathologies of between-groups principal components analysis in geometric morphometrics. Evol. Biol. 46, 271-302. (doi:10.1007/s11692-019-09484-8)

65. Cardini A. 2020 Modern morphometrics and the study of population differences: good data behind clever analyses and cool pictures? Anat. Rec. 303, 2747-2765. (doi:10.1002/ar.24397)

66. Rohlf FJ, Slice D. 1990 Extensions of the Procrustes method for the optimal superimposition of landmarks. Syst. Zool. 39, 40-59. (doi:10.2307/2992207) 
67. Mitteroecker P, Bookstein F. 2011 Linear discrimination, ordination, and the visualization of selection gradients in modern morphometrics. Evol. Biol. 38, 100-114. (doi:10.1007/s11692-011-9109-8)

68. MacLeod N. 2005 Principal components analysis (eigenanalysis \& regression 5). Palaeontol. Assoc. News 59, 44-57.

69. Hackett SJ et al. 2008 A phylogenomic study of birds reveals their evolutionary history. Science 320, 1763-1768. (doi:10.1126/science.1157704)

70. Catalano SA, Goloboff PA, Giannini NP. 2010 Phylogenetic morphometrics (I): the use of landmark data in a phylogenetic framework. Cladistics 26, 539-549. (doi:10.1111/j.1096-0031.2010.00302.x)

71. Sidlauskas B. 2008 Continuous and arrested morphological diversification in sister clades of characiform fishes: a phylomorphospace approach. Evolution 62, 31353156. (doi:10.1111/j.1558-5646.2008.00519.x)

72. R Core Team. 2020 R: a language and environment for statistical computing. Vienna, Austria: R Foundation for Statistical Computing. See https://www.R-project.org/.

73. Schlager S. 2017 Morpho and rvcg - shape analysis in R: R-packages for geometric morphometrics, shape analysis and surface manipulations. In Statistical Shape and Deformation Analysis (eds G Zheng, S Li, G Székely), pp. 217-256. Academic Press. (doi:10.1016/B978-0-12-810493-4.00011-0)

74. Adams DC, Otárola-Castillo E, Kaliontzopoulou A. 2020 geomorph: software for geometric morphometric analyses. See https://cran.r-project.org/package=geomorph.

75. Dryden IL. 2019 shapes: statistical shape analysis. See https://CRAN.Rproject.org/package=shapes.

76. Plate T, Heiberger R, Plate MT. 2016 abind: combine multidimensional arrays. See https://CRAN.R-project.org/package=abind. 
77. Sterratt DC, Lyngholm D, Willshaw DJ, Thompson ID. 2013 Standard anatomical and visual space for the mouse retina: computational reconstruction and transformation of flattened retinae with the retistruct package. PLoS Comput. Biol. 9, e1002921. (doi:10.1371/journal.pcbi.1002921)

78. Bivand RS, Wong DWS. 2018 Comparing implementations of global and local indicators of spatial association. TEST 27, 716-748. (doi:10.1007/s11749-018-0599-x)

79. Paradis E, Schliep K. 2019 ape 5.0: an environment for modern phylogenetics and evolutionary analyses in R. Bioinformatics $35, \quad 526-528$. (doi:10.1093/bioinformatics/bty633)

80. Revell LJ. 2012 phytools: an R package for phylogenetic comparative biology (and other things). Methods Ecol. Evol. 3, 217-223. (doi:10.1111/j.2041-210X.2011.00169.x)

81. Rohlf FJ. 2016 tpsDig, version 2.26. See http://life. bio. sunysb. edu/morph/softdataacq. html.

82. Goloboff PA, Farris JS, Nixon KC. 2008 TNT, a free program for phylogenetic analysis. Cladistics 24, 774-786. (doi:10.1111/j.1096-0031.2008.00217.x)

83. Payne RB. 1984 Sexual selection, lek and arena behavior, and sexual size dimorphism in birds. Ornithol. Monogr. , iii-52. (doi:10.2307/40166729)

84. Barraclough TG, Harvey PH, Nee S. 1995 Sexual selection and taxonomic diversity in passerine birds. Proc. Royal Soc. B 259, 211-215. (doi:10.1098/rspb.1995.0031)

85. Klingenberg CP. 1998 Heterochrony and allometry: the analysis of evolutionary change in ontogeny. Biol. Rev. 73, 79-123. (doi:10.1017/S000632319800512X)

86. Andersson M. 2019 Sexual selection. Princeton University Press. See https://www.degruyter.com/document/doi/10.1515/9780691207278/html.

87. Møller AP, Barbosa A, Cuervo JJ, Lope F de, Merino S, Saino N. 1998 Sexual selection and tail streamers in the barn swallow. Proc. Royal Soc. B 265, 409-414. (doi:10.1098/rspb.1998.0309) 
88. Møller AP. 1988 Female choice selects for male sexual tail ornaments in the monogamous swallow. Nature 332, 640-642. (doi:10.1038/332640a0)

89. Balmford A, Thomas ALR, Jones IL. 1993 Aerodynamics and the evolution of long tails in birds. Nature 361, 628-631. (doi:10.1038/361628a0)

90. Winquist T, Lemon RE. 1994 Sexual selection and exaggerated male tail length in birds. Am. Nat. 143, 95-116. (doi:10.1086/285597)

91. Clark CJ. 2010 The evolution of tail shape in hummingbirds. The Auk 127, 44-56. (doi:10.1525/auk.2009.09073)

92. Hunt G, Hopkins MJ, Lidgard S. 2015 Simple versus complex models of trait evolution and stasis as a response to environmental change. PNAS 112, 4885-4890. (doi:10.1073/pnas.1403662111)

93. Evans MR, Thomas ALR. 1997 Testing the functional significance of tail streamers. Proc. Royal Soc. B 264, 211-217. (doi:10.1098/rspb.1997.0030)

94. Evans MR. 2004 Limits on the evolution of tail ornamentation in birds. Am. Nat. 163, 341-358. (doi:10.1086/381770)

95. Saino N, Møller AP. 1996 Sexual ornamentation and immunocompetence in the barn swallow. Behav. Ecol. 7, 227-232. (doi:10.1093/beheco/7.2.227)

96. Cuervo JJ, Møller AP. 2001 Components of phenotypic variation in avian ornamental and non-ornamental feathers. Evol. Ecol. 15, 53-72. (doi:10.1023/A:1011913804309) 
Table 1. Procrustes distances implied in shape transformations for intraspecific allometric and intersexes variation, along with the residual degrees of freedom, $F$ values and $p$-values from Procrustes Linear Models. Significant allometric patterns or sexual dimorphism are highlighted in bold.

\begin{tabular}{|c|c|c|}
\hline & Allometric variation & Sexual dimorphism \\
\hline T. albogularis & $\begin{array}{c}0.044(\mathrm{df}=14 ; \mathrm{F}=0.48 ; \mathrm{p}= \\
0.679)\end{array}$ & $\begin{array}{c}0.059(\mathrm{df}=14 ; \mathrm{F}=3.14 ; p= \\
0.042)\end{array}$ \\
\hline T. caudifasciatus & $\begin{array}{c}0.065(\mathrm{df}=19 ; \mathrm{F}=1.24 ; \mathrm{p}= \\
0.242)\end{array}$ & $\begin{array}{c}0.015(\mathrm{df}=19 ; \mathrm{F}=0.21 ; \mathrm{p}= \\
0.890)\end{array}$ \\
\hline T. couchii & $\begin{array}{c}0.042(\mathrm{df}=15 ; \mathrm{F}=0.77 ; \mathrm{p}= \\
0.470)\end{array}$ & $\begin{array}{c}0.017(\mathrm{df}=15 ; \mathrm{F}=0.43 ; \mathrm{p}= \\
0.739)\end{array}$ \\
\hline T. crassirostris & $\begin{array}{c}0.037(\mathrm{df}=18 ; \mathrm{F}=0.41 ; \mathrm{p}= \\
0.682)\end{array}$ & $\begin{array}{c}0.052(\mathrm{df}=18 ; \mathrm{F}=3.05 ; \mathrm{p}= \\
0.076)\end{array}$ \\
\hline T. cubensis & $\begin{array}{c}0.089(\mathrm{df}=10 ; \mathrm{F}=1.21 ; \mathrm{p}= \\
0.290)\end{array}$ & $\begin{array}{c}0.021(\mathrm{df}=10 ; \mathrm{F}=0.22 ; p= \\
0.873)\end{array}$ \\
\hline T. dominicensis & $\begin{array}{c}0.035(\mathrm{df}=19 ; \mathrm{F}=0.55 ; \mathrm{p}= \\
0.645)\end{array}$ & $\begin{array}{c}0.031(\mathrm{df}=19 ; \mathrm{F}=1.15 ; \mathrm{p}= \\
0.319)\end{array}$ \\
\hline T. forficatus & $\begin{aligned} 0.116(d f= & 18 ; F=15.26 ; p> \\
& 0.001)\end{aligned}$ & $\begin{aligned} 0.064(\mathrm{df}= & 18 ; \mathrm{F}=13.44 ; \mathrm{p}> \\
& 0.001)\end{aligned}$ \\
\hline T. melancholicus & $\begin{array}{c}0.039(\mathrm{df}=37 ; \mathrm{F}=0.31 ; \mathrm{p}= \\
0.759)\end{array}$ & $\begin{array}{c}0.010(\mathrm{df}=37 ; \mathrm{F}=0.13 ; \mathrm{p}= \\
0.928)\end{array}$ \\
\hline T. niveigularis & $\begin{array}{c}0.069(\mathrm{df}=17 ; \mathrm{F}=1.12 ; \mathrm{p}= \\
0.275)\end{array}$ & $\begin{array}{c}0.023(\mathrm{df}=17 ; \mathrm{F}=0.45 ; \mathrm{p}= \\
0.608)\end{array}$ \\
\hline T. savana & $\begin{array}{c}0.165(\mathrm{df}=27 ; \mathrm{F}=20.28 ; p> \\
0.001)\end{array}$ & $\begin{aligned} 0.070(\mathrm{df}= & 27 ; \mathrm{F}=10.95 ; \mathrm{p}> \\
& 0.001)\end{aligned}$ \\
\hline T. tyrannus & $\begin{aligned} 0.075(\mathrm{df}= & 24 ; \mathrm{F}=3.02 ; \mathrm{p}= \\
& 0.06)\end{aligned}$ & $\begin{array}{c}0.023(\mathrm{df}=24 ; \mathrm{F}=0.78 ; \mathrm{p}= \\
0.427)\end{array}$ \\
\hline T. verticalis & $\begin{array}{c}0.038(\mathrm{df}=19 ; \mathrm{F}=0.36 ; \mathrm{p}= \\
0.718)\end{array}$ & $\begin{array}{c}0.011(\mathrm{df}=19 ; \mathrm{F}=0.14 ; \mathrm{p}= \\
0.943)\end{array}$ \\
\hline T. vociferans & $\begin{array}{c}0.028(\mathrm{df}=18 ; \mathrm{F}=0.71 ; \mathrm{p}= \\
0.519)\end{array}$ & $\begin{array}{c}0.013(\mathrm{df}=18 ; \mathrm{F}=0.52 ; \mathrm{p}= \\
0.729)\end{array}$ \\
\hline
\end{tabular}

Table 2.Pearson correlations between the allometric and intersexes axes of each species and the $\mathrm{BMV}$, along with the $\mathrm{p}$-value from permutation tests. Statistically significant results are highlighted in bold.

\begin{tabular}{|c|c|c|c|}
\hline & $\begin{array}{l}\text { Allometric - } \\
\text { Intersexes }\end{array}$ & $\begin{array}{l}\text { Allometric - } \\
\text { Interspecific }\end{array}$ & $\begin{array}{l}\text { Intersexes - } \\
\text { Interspecific }\end{array}$ \\
\hline T. albogularis & $0.677(p=0.028)$ & $0.081(p=0.654)$ & $0.232(p=0.407)$ \\
\hline T. caudifasciatus & $0.517(p=0.123)$ & $0.377(p=0.181)$ & $-0.391(p=0.371)$ \\
\hline T. couchii & $0.761(p=0.008)$ & $-0.032(p=0.971)$ & $0.199(p=0.495)$ \\
\hline T. crassirostris & $0.190(p=0.603)$ & $-0.492(p=0.171)$ & $-0.226(p=0.348)$ \\
\hline T. cubensis & $-0.334(p=0.344)$ & $0.026(p=0.123)$ & $0.421(p=0.322)$ \\
\hline T. dominicensis & $0.508(p=0.153)$ & $-0.382(p=0.337)$ & $-0.793(p=0.017)$ \\
\hline T. forficatus & $0.987(p>0.001)$ & $-0.98(p>0.001)$ & $-0.97(p>0.001)$ \\
\hline T. melancholicus & $0.451(p=0.191)$ & $-0.500(p=0.084)$ & $-0.047(p=0.804)$ \\
\hline T. niveigularis & $0.897(p=0.002)$ & $-0.087(p=0.712)$ & $0.117(p=0.860)$ \\
\hline
\end{tabular}


bioRxiv preprint doi: https://doi.ora/10.1101/2021.07.09.451836: this version posted Julv 11. 2021. The copvriaht holder for this preprin (which was not certified by peer review) is the author/funder, who has granted bioRxiv a license to display the preprint in perpetuity. It is made available under aCC-BY-NC-ND 4.0 International license.

\begin{tabular}{|l|c|c|c|}
\hline T. savana & $\mathbf{0 . 9 7 4}(\mathbf{p}>\mathbf{0 . 0 0 1})$ & $\mathbf{- 0 . 6 6 6}(\mathbf{p}=\mathbf{0 . 0 3 8})$ & $\mathbf{- 0 . 6 5 6}(\mathbf{p}=\mathbf{0 . 0 3 4})$ \\
\hline T. tyrannus & $\mathbf{0 . 8 1 0}(\mathbf{p}=\mathbf{0 . 0 0 4})$ & $0.282(p=0.291)$ & $-0.208(p=0.690)$ \\
\hline T. verticalis & $0.154(p=0.672)$ & $0.048(p=0.700)$ & $0.419(p=0.244)$ \\
\hline T. vociferans & $0.339(p=0.339)$ & $-0.497(p=0.210)$ & $0.368(p=0.211)$ \\
\hline
\end{tabular}

Table 3. Accumulated correlations between ancestral axes of intraspecific variation and the ancestral WMV (left) or the interdescendants axis (right), associated with each ancestordescendants comparison. Values are relativised to the highest value of each column.

\begin{tabular}{|c|c|c|c|c|}
\hline & $\begin{array}{l}\text { vs. ancestral axis } \\
\text { of major } \\
\text { intraspecific } \\
\text { variation }\end{array}$ & & $\begin{array}{c}\text { vs. major axis of } \\
\text { inter-descendant } \\
\text { variation }\end{array}$ & \\
\hline & $\begin{array}{l}\text { Regular clade } \\
\text { contrasts }\end{array}$ & $\begin{array}{l}\text { Deep-fork species } \\
\text { related contrasts }\end{array}$ & $\begin{array}{l}\text { Regular clade } \\
\text { contrasts }\end{array}$ & $\begin{array}{l}\text { Deep-fork species } \\
\text { related contrasts }\end{array}$ \\
\hline Residual & 1 & 1 & 1 & 0.199 \\
\hline Allometric & 0.548 & 0.810 & 0.623 & 0.484 \\
\hline Intersexual & 0.611 & 0.588 & 0.540 & 1 \\
\hline
\end{tabular}

Supplementary Table 1. Results from regressions of tail size on body size for both raw and sexually corrected estimates of size. Statistically significant results are highlighted in bold.

\begin{tabular}{|c|c|c|c|c|c|c|c|c|}
\hline & Raw & & & & $\begin{array}{l}\text { Sexually- } \\
\text { corrected }\end{array}$ & & & \\
\hline & $\begin{array}{l}\text { Residual } \\
\text { df }\end{array}$ & $\begin{array}{l}\mathrm{F} \\
\text { values }\end{array}$ & $\begin{array}{l}\mathrm{p}- \\
\text { values }\end{array}$ & Slopes & $\begin{array}{l}\text { Residual } \\
\text { df }\end{array}$ & $\begin{array}{l}\mathrm{F} \\
\text { values }\end{array}$ & $\begin{array}{l}\mathrm{p}- \\
\text { values }\end{array}$ & Slopes \\
\hline T. albogularis & 14 & 0,437 & 0,52 & 0,181 & 14 & 0,557 & 0,468 & 0,196 \\
\hline $\begin{array}{l}T . \\
\text { caudifasciatus }\end{array}$ & 19 & 0,006 & 0,939 & $-0,031$ & 19 & 0,03 & 0,865 & 0,079 \\
\hline T. couchii & 12 & 0,842 & 0,377 & 0,337 & 12 & 0,544 & 0,475 & 0,252 \\
\hline T. crassirostris & 18 & 0,553 & 0,467 & 0,179 & 18 & 0,373 & 0,549 & 0,162 \\
\hline T. cubensis & 10 & 0,86 & 0,375 & $-0,567$ & 10 & 1,074 & 0,325 & $-0,663$ \\
\hline T. dominicensis & 19 & 0,047 & 0,831 & 0,057 & 19 & 0,486 & 0,494 & 0,201 \\
\hline T. forficatus & 18 & 16,004 & 0,001 & 4,793 & 18 & 0,067 & 0,799 & 0,29 \\
\hline $\begin{array}{l}T . \\
\text { melancholicus }\end{array}$ & 36 & 0,001 & 0,973 & $-0,006$ & 36 & 0,064 & 0,801 & 0,047 \\
\hline T. niveigularis & 16 & 8,399 & 0,01 & 1,368 & 16 & 7,613 & 0,014 & 1,403 \\
\hline T. savana & 27 & 9,112 & 0,005 & 3,025 & 27 & 0,004 & 0,951 & $-0,055$ \\
\hline T. tyrannus & 21 & 28,512 & $>0,001$ & 1,073 & 21 & 34,599 & $>0,001$ & 0,892 \\
\hline T. verticalis & 18 & 3,598 & 0,074 & 0,525 & 18 & 2,067 & 0,168 & 0,486 \\
\hline T. vociferans & 15 & 0,208 & 0,655 & $-0,191$ & 15 & 0,411 & 0,531 & $-0,285$ \\
\hline
\end{tabular}




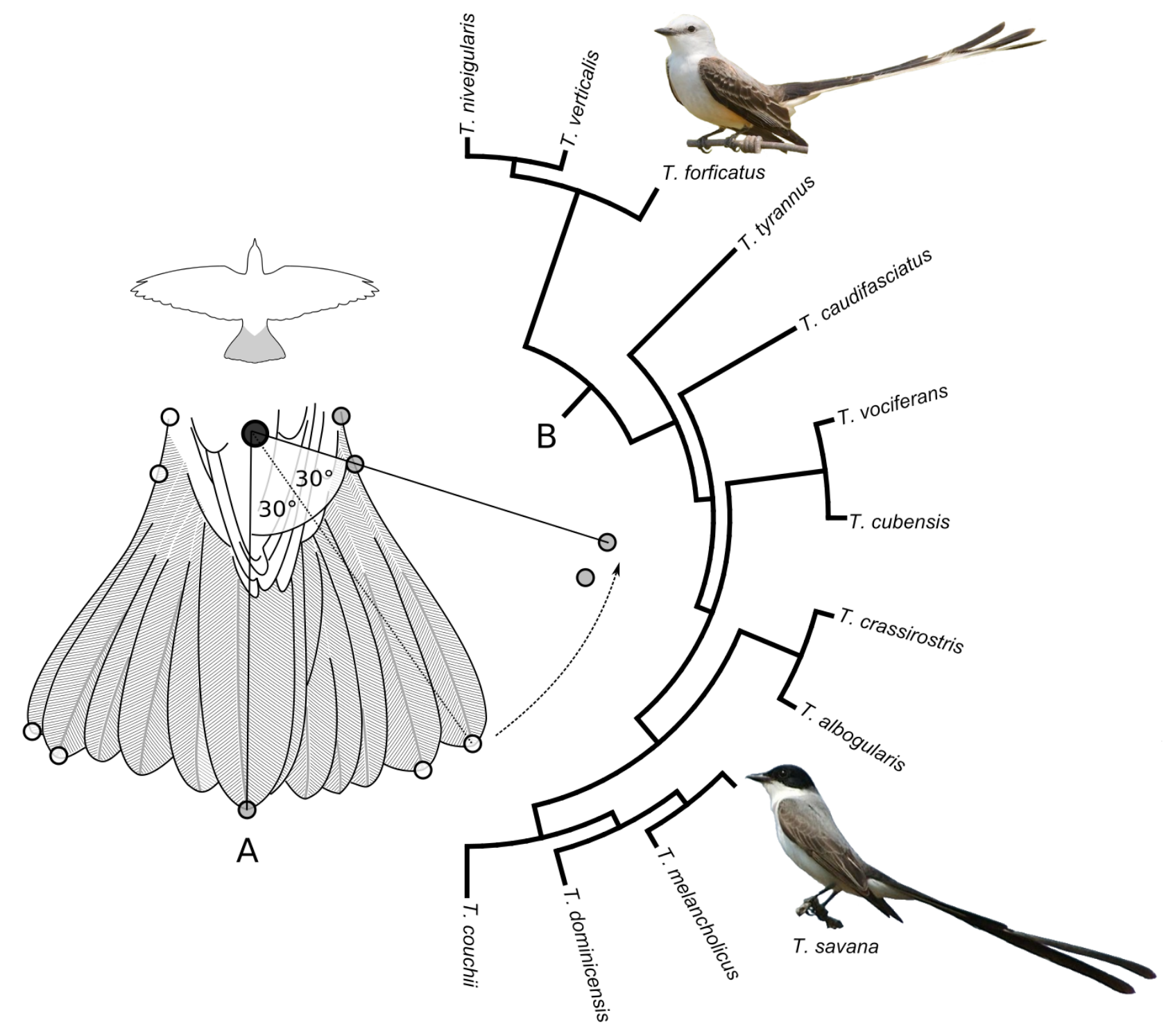

Figure 1. A) Schematic representation of a bird tail, showing the original and post-rotated position of the nine landmarks (semi-open circles), as well as the centroid of the tail base (larger closed circle) used as pivot; only right-sided landmarks (semi-open gray circles) were retained for further analysis. B) Cladogram of the Tyrannus species [48], with the two deep-fork tailed species depicted. 
bioRxiv preprint doi: https://doi.org/10.1101/2021.07 09.451836; this version posted July 11, 2021. The copyright holder for this preprin (which was not certified by peer review) is the author/funder, who has granted bioRxiv a license to display the preprint in perpetuity. It is made available under aCC-BY-NC-ND 4.0 International license.

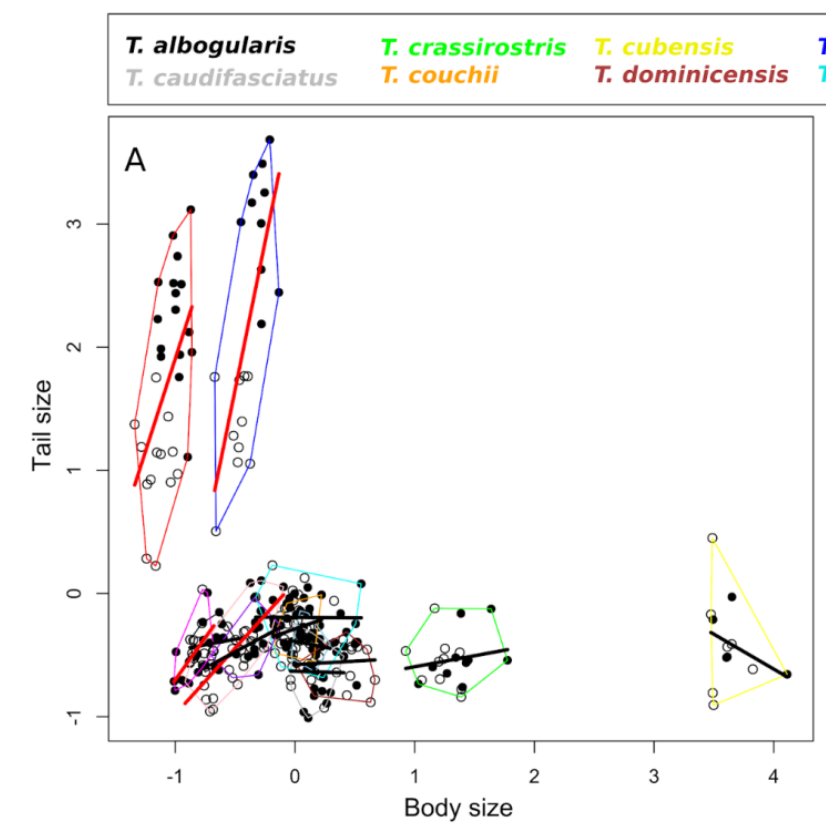

T. forficatus T. niveigularis

T. tyrannus T. vociferans

melancholicus T. savana T. verticalis

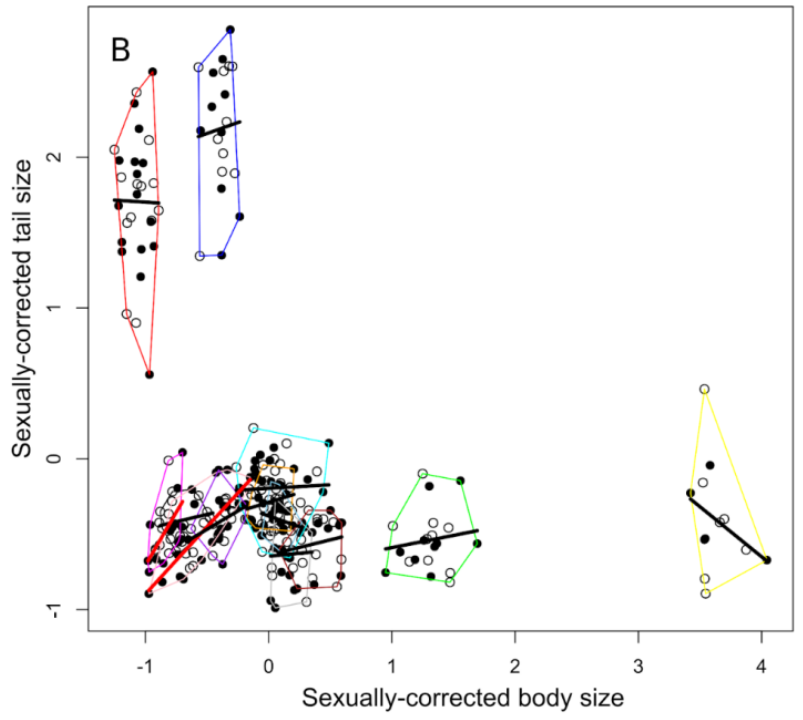

Figure 2. Z-standardized raw (A) and sexually-corrected (B) tail size versus body size plots. Open circles represent females, whereas closed circles represent males. Solid thick lines are linear regression trend lines; Red lines indicate slopes significantly different from 0. 
bioRxiv preprint doi: https://doi.org/10.1101/2021.07 09.451836; this version posted July 11, 2021. The copyright holder for this preprint (which was not certified by peer review) is the author/funder, who has granted bioRxiv a license to display the preprint in perpetuity. It is made available under aCC-BY-NC-ND 4.0 International license.

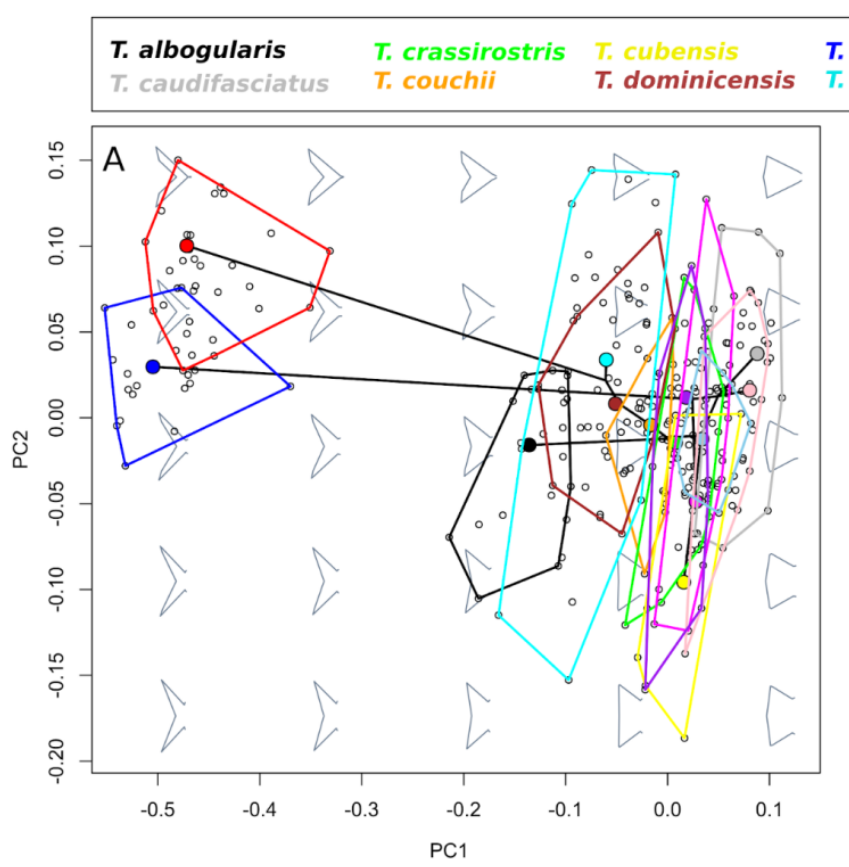

\begin{tabular}{llll|} 
T. forficatus & T. niveigularis & T. tyrannus & T. vociferans \\
T. melancholicus & T. savana & T. verticalis &
\end{tabular}
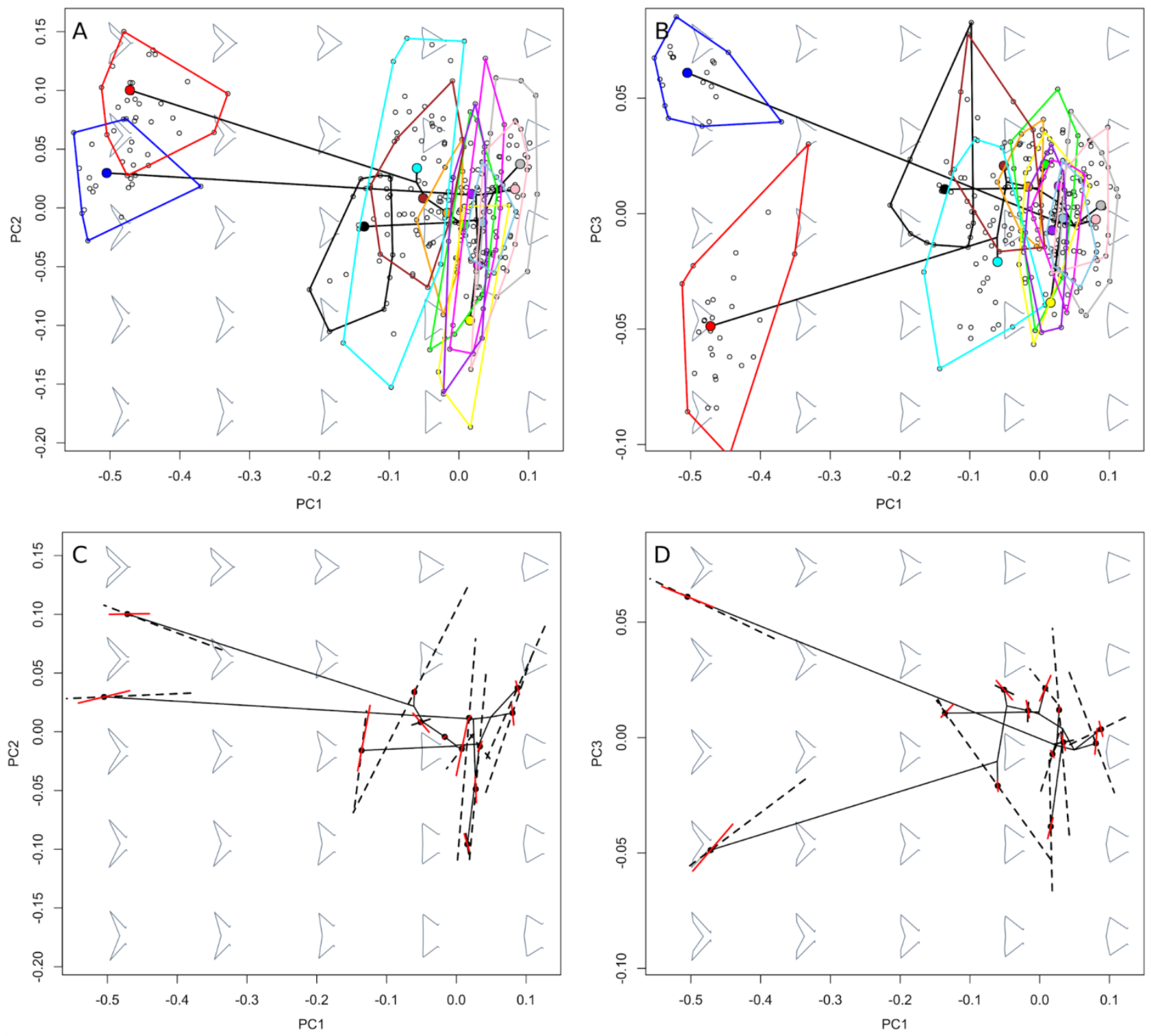

Figure 3. A-B) Phylomorphospaces formed by the first three bgPCs displaying the distribution of the full sample of allometrically- and sexually-corrected specimens (open circles) and species' mean shapes (coloured closed circles). C-D) Intraspecific axes of morphological variation (allometric variation: black dashed lines; intersexes variation: solid red lines) projected into phylomorphospace and centered around each species' mean shape. 
PC1

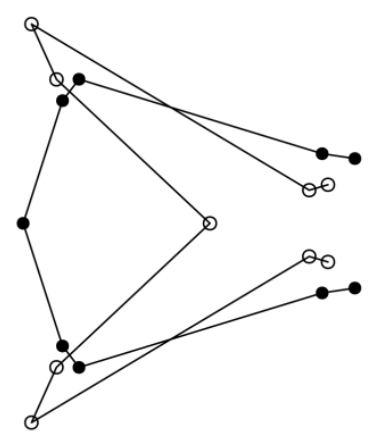

PC2

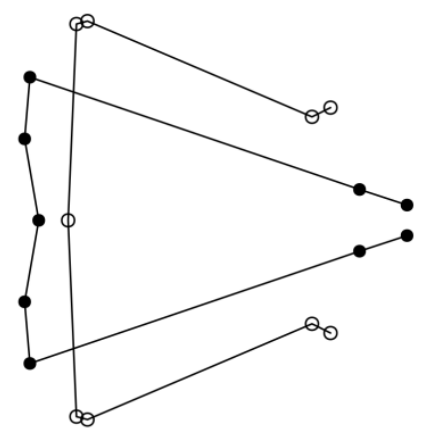

PC3

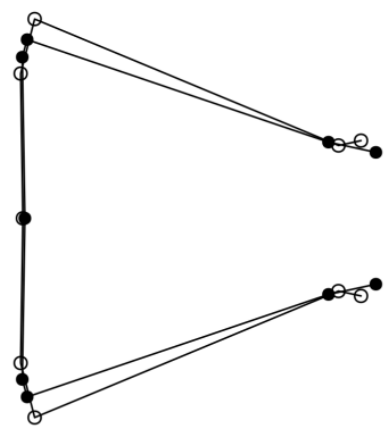

Supplementary Figure S1. Shape transformations represented by the first three Principal Components resulting from PCA of Procrustes shape coordinates of NDF Tyrannus species. Open circles are used for landmarks of the configuration representing negative extremes, whereas closed circles are used for positive extremes. 